\title{
Improving The Creativity Of Learning Food Production Through Portfolio Assessment In The Project Learning Model
}

\author{
Ni Desak Made Sri Adnyawati, ${ }^{1, *}$ \\ ${ }^{1}$ PKK, Engineering and Vocational Faculty, 81116 Undiksha Singaraja, Bali
}

\begin{abstract}
The implementation of the portfolio assessment in the project learning model is intended to identify the improvement made by the students in the food production learning, and the response given by the students to the implementation of the portfolio assessment in the project learning model. This classroom action research involved 23 students from the study program of food production of Ganesha University of Education during 2014/2015 academic year. The study was conducted in two cycles through the stage in which it was designed, the stage in which it was implemented, the stage in which observation was made, and the stage in which reflection was evaluated. The data were collected using the observation technique in which the learning process and product were observed. The observation sheet of process included preparing, processing, and serving dishes. The observation sheet of products included appearance, texture, aroma and taste aspects through the organoleptic test. The data were descriptively analyzed. The result of the study showed that the learning creativity of food production in cycle 1 averaged 79.15 and could be categorized as good, in cycle 2 the learning creativity averaged 87.08 and could be categorized as very good. This means that the improvement of the learning creativity of food production made by the students through the implementation of the portfolio assessment in the learning project was 7.93. The response given by the students to the implementation of the portfolio assessment in the project learning model could be categorized as good and averaged 81.27. Keywords: portfolio assessment, food production creativity, project learning model.
\end{abstract}

\section{Introduction}

Vocational education is education which provides skills through trainings as part of the learning process. The food production learning, as one of the vocational educations, is established to concentrate on the food production education. It emphasizes the stage in which foods are processed and the stage in which foods are ready to be served. There are three stages in the food production learning activity; they are the process of planning, processing, and serving foods. In the planning stage the materials and tools needed were planned, the processing process included the tools and technique used to process foods, and

* Corresponding author: adnyawatisri@yahoo.com 
the serving stage included the tools and technique needed to serve foods, and the quality of what was served.

So far at the Engineering and Vocational Faculty of Ganesha University of Education, assignments have been collaboratively divided between the students and the teaching staff in the food production learning. The orientation of the food production learning is that there will be final learning products in the form of foods. From what was observed it can be stated that the learning process and products could not be clearly controlled; as a consequence, the learning outcome had not been optimal yet. The laboratory activity took a long time, the materials and tools needed were improperly prepared, causing the food products not to fulfill the criteria. Therefore, the learning activity should be packaged through accurate assessments in order to maximize the learning process and learning outcome of food production.

The learning process and learning outcome of food production were observed through portfolio. According to Fajar (2004), the word portfolio is derived from the English word 'portfolio', meaning documents. It can also be defined as a collection of valuable papers of a particular job. Portfolio is often collocated with learning; as a result, the portfolio-based learning has appeared. However, if it is collocated with the assessment concept the term portfolio-based assessment has appeared (Budimansyah, 2002). The steps in the portfoliobased learning method, aaccording to Center For Civic Education (in Depdiknas, 2004) include: 1) identifying the problems in society; 2) sorting the problems to analyze in the classroom; 3) collecting information on the problem to analyze in the classroom; 4) making portfolio; 5) presenting portfolio (showing case).

According to Cole, Ryan and Kick as quoted by Wahyudi (2010), there are two types of portfolio, namely the process portfolio and the product portfolio. The process portfolio shows the learning stages and presents the notes of the development of learners from time to time. The product portfolio is a form of the portfolio assessment emphasizing the mastery of the material required by the assignment in the standardized competence, basic competence, and indicator of the achievement of the learning outcome shown through documents.

Portfolio is a collection of artifacts showing the development and what is achieved by learners in a learning program (Marhaeni, 2007). It means that the real work in a project can be controlled using portfolio. According to Surapranata and Hatta (2004), portfolio is defined as a collection of systematically organized works or documents of learners taken during the learning process. It is used by the teaching staff and learners to assess and evaluate the development of the learners' knowledge, skill and attitude in a particular learning process.

Utami Munandar (1992: 21) stated that creativity is the ability to create something new, give new concepts which can be implemented in problem solving. In the learning process, learners are demanded to learn creatively in order to create something new. Creativity refers to the ability of someone to produce composition, product or concept, whatever they are; the important thing is that they are new and who create them has not been identified before. Creativity can be in the forms of an art product, a literary work, a scientific product, or it can be in the form of a procedure or methodology. Suarni (1996) stated that "creativity is the ability to create something. What is created is not necessarily entirely new; what is new can be its combination whose elements are already available before". Creativity is not always in the form a new creation. Creative products often appear as a result of the combination of what has been already available or can adopt the superiority of the elements of what has been created before. The observation of the design is finally in the form of a real work made using portfolio. Portfolio is a collection of artifacts showing the development and what is achieved by the learners in a learning program (Marhaeni, 2007). That means that the real work of a project can be controlled 
using portfolio. Creative learning is the ability reflecting fluency, flexibility, and originality in the way of thinking and the ability to collaborate a concept (Utami Munandar, 1992: 42). According to Triffenger, as quoted by Conny Setiawan (1990: 37-38), there are three reasons why creating learning is important; they are 1) being able to help children learn more successfully in the learning process, 2) being able to create the possibilities of solving the problem which we cannot predict, 3) being able to lead to great satisfaction and enjoyment.

The creativity as an indicator in the food production learning is shown in the learning process and outcome. Suarni (1996) stated that creativity is the ability to create something. What is created is not necessarily entirely new; what is new can be its combination, and the elements which are combined have already been previously available. Creativity is the ability to develop new ideas and new ways of solving problems and thinking about new things. The application of creativity in the framework of solving problems and discovering new things requires ability referred to as innovation, meaning that there is newness. The creative and innovative abilities are really reflected in the ability and desire to start up, the ability to do something new (creative), the ability to search out opportunities, being brave to bear risk and the ability to develop ideas. Such abilities and desires are required to: (1) apply new techniques; (2) produce new products or services; (3) produce new added value; (4) clear a path for a new business which is oriented towards the market; (5) develop a new organization (Rizqidiaz, 2011).

Such new and different things can be in the forms of a product and service, and a process such as an idea, method, and manner. The new and different things created through the process of creative thinking and creative action are the added value and valuable superiorities which are aimed at by the food production learning. The food production learning can be made to be a more interesting and meaningful learning experience for adults, or a traditional training in order to support the work skill (Gaer, 1998). In the food production learning, learners become motivated to learn more actively; the teacher is only the facilitator; the teacher evaluates the product as the result of the learners' performance including the outcome which can be displayed from the result of the project done. This learning emphasizes the environment in which students learn actively and collaboratively, and the authentic technique assessment is applied. The project learning is a comprehensive learning in which learners are continuously involved and cooperatively observed. The project learning focuses on the core concept and principle, facilitates learners to investigate, solve problems, and do other assignments and produce real products. It is student-centered learning (Santyasa, 2007). Then Nanang Hanafiah and Cucu Suhana (2009) state that the project learning model is the learning approach which allows leaners to work independently and construct their own learning which is culminated in a real product. This type of learning emphasizes the environment in which students learn actively and work collaboratively, and the authentic assessment technique is applied. The portfolio is one of the authentic assessments. It is not wrong if it is used in the project learning model in order to improve the creativity of learning food production.

The superiorities of the application of the portfolio assessment in the project learning are : a) it can be used to assess students based on all the assignments and the products which have been done and related to the performance assessed, b) students participate in assessing the progress they have made in completing different assignments, and the development which has taken place during the learning process, c) it can be used to assess every student based on what has been respectively achieved by taking individual differences into consideration, d) it can be used to realize the collaborative assessment process, e) students can assess themselves as what is aimed at, f) the assessment focuses on the progress achieved, the attempt made, and what has been achieved, g) it cannot be separated from the assessment, teaching and learning processes. 
Based on what is described above, this present study is intended to identify 1) the improvement of the creativity in the food production learning through the portfolio assessment in the project learning, and 2) the response given by students to the application of the portfolio assessment in the project learning model.

\section{Research Model}

This present study is a classroom action research involving 23 students of the study program of food production education during the 2014/2015 academic year. It was conducted in two learning cycles; each was made up of four stages. They are (1) the action design, (2) the action implementation, (3) the observation and evaluation, and (4) the reflection. Each cycle was conducted in four learning times.

The data which were collected are 1) the data on the students' learning creativity including preparing, processing, serving collected through observation sheet; 2) the data on the response given by the students collected through questionnaire. The data were descriptively analyzed with the criterion that the students' learning outcome improved from cycle I to cycle II. The data on the response given by the students were descriptively analyzed with the criterion that the improvement made by the students in the response they gave was under the positive category.

\section{Result and Discussion}

This classroom action research involved the students who had programmed the course of food creativity 'Cipta Karya Boga', as one of the courses under the food production learning. The students totaled 23; they were grouped into five groups, two groups were made up of four students, and three groups were made up of five students. The learning process was packaged into two cycles; each was implemented in four sessions with five steps of the project learning. Each session was held once a week and took place for four lecturing hours.

In the beginning of the learning process, the teaching staff, in this case, the lecturer informed that the learning activity in the class room for the course food creativity 'Cipta Karya Boga' was delivered using the project learning model. The lecturer informed that the assessment model applied during the learning process included design, processing, and serving using the portfolio assessment. Then the lecturer gave a general picture of the portfolio assessment and the types of what was expected from them which were then used as the students' portfolio. What was expected would be used as the portfolio including the design of the modern menu structure, the process of realizing the design, the product which was expected based on the criterion, and the report containing the food creativity.

The learning creativity was adjusted to the steps taken in the project learning. Step (1) started with a big question; this was done by offering a problem with the theme the use of the local material in the design of the modern menu structure. In step (2) a plan for the project was designed; in this step the students designed the modern menu structure using the local material; preparing, processing and serving activities were innovated. The modern menu structure was made up of the appetizer, entrée, main course, and dessert. In step (3) a schedule was created; in this step the schedule containing when the material was prepared, the time needed for that, the tools needed, the process, and the time when the project would be completed was made. In step (4) the students and the progress made by the students were monitored; the design and the real design made in the production laboratory were discussed in and outside the classroom. In step (5) the outcome was assessed; the completion of the menu was observed so that the product produced would meet the criterion already 
determined. In the step when the experience was evaluated, the aspects of appearance, aroma, texture, and taste of the menu as the final product were tested using the organoleptic test.

The students' creativity obtained from the result of observation and evaluation in cycle I showed that the portfolio averaged 79.15. Based on the criterion of classification already determined, the criterion of the students' criterion in cycle I was under the category good. In this cycle the students' weakness in the menu design to label the menu was weak. The application of the principle of variation in how to arrange the menu was still poor, giving the impression that the menu design was monotonous. This could be seen from the material and the technique which finally affected the texture, taste and serving variation. It seemed that the time needed for completing the menu product was not maximally controlled and this contributed to the quality of the result.

The result of evaluation in cycle I was deeply reflected both in the preparation, process and completion. Improvement was made by emphasizing the learning process with the portfolio assessment through the steps in which the project learning model was applied. The innovation made for the menu in the second menu structure was observed. It was obtained that in cycle II the students' creativity averaged 87.08 , which was under the category very good. This showed that the improvement made by the students in the learning process was significant. The menu designed through the project in which the local material was used in the modern menu structure had been maximally produced. The original menu as the project innovation, the material used, the technique used in the steps in which the product was realized showed the maximum attempts which had been made by the students. How the appetizer, entrée, main course and dessert were arranged varied depending on the material used, the processing and serving techniques; therefore, the quality of performance, aroma, texture, and taste were under the category good.

The data on the response in the food production learning using the portfolio assessment in the project learning model collected through the response given by the students in the end of cycle II averaged 81.27 and under the category good. Based on the result obtained from cycle I and cycle II, it can be stated that the action taken could improve the food production learning activity, resulting from the application of the portfolio assessment in the learning project. This gives wide opportunities to the students to learn food production creatively. The students have opportunities to develop their attitude and skill in the learning process. The optimal mastery of the process can help them to be creative. The balance between the process and product are two sides which support each other in the food production learning. The portfolio assessment in the project learning model can also give wide opportunities to the students to be innovative in designing, processing and serving foods as the periodic observation can motivate them to work better. Being happy to learn food production through the application of the portfolio assessment in the project learning model is important to support the learning success.

The result of the present study is also supported by the study previously conducted by Lucy Sri Musmini (2012) that the portfolio assessment could also contribute to the students' positive way of thinking. In addition, the results of the studies conducted by I A Made Wedasuwari (2013) and Abdorreza Tahriri (2014) showed that the implementation of the portfolio assessment could improve the students' knowledge and skill in writing.

From what is described above and the reflection made, the superiorities of the portfolio assessment in the project learning model are as follows; 1) the students become the learning center; 2) the students can evaluate themselves; 3 ) the lecturer can use it for controlling the students' learning activity; 4) it gives both the students and lecturer responsibility; 5) the learning process becomes more systematic and guided causing the learning process to be effective. 


\section{Conclusion}

Based on the problems of the study and the result of analysis, it can be concluded that the implementation of the portfolio assessment in the project learning model could improve the activity of learning food production. In cycle 1 the learning creativity averaged 79.15 and could be categorized as good and in cycle 2 the learning creativity averaged 87.08 and could be categorized as very good, meaning that the creativity of leaning food production through the implementation of the portfolio assessment in the project learning improved by 7.93. The response given by the students to the implementation of the portfolio assessment in the project learning model could be categorized as good and averaged 81.27.

\section{References}

1. Abdorreza Tahriri. The Effect of Portfolio Assesment on Learning Idioms in Writing. International Journal of Education \& Literacy Studies. Vol.2. (2014)

2. Budimansyah, Dasim. Model Pembelajaran dan Penelitian Portofolio. Bandung: PT. Genesindo. (2002).

3. Dedi Supriadi. Kreativitas Kebudayaan dan Perkembangan IPTEK. Bandung: ALFABETA. (1994)

4. Fajar, Arnie. Portofolio dalam Pembelajaran IPS. Bandung : PT. Remaja Rosdakarya. (2004)

5. Gaer, S. What is Project based learning? (Online), (http://members.aol.com/Culebra Mom/ pblprt.html, diakses 26 Juli 2017). (1998)

6. Irma Sumarsih. Implementasi Pembelajaran Kooperatif Tipe STAD untuk Meningkatkan Kreativitas Belajar Matematika Siswa SMP. (2008).

7. Julius Chandra. Kreativitas. Yogyakarta: Kanisius. (1994).

8. Marhaeni \& Budi Adnyana. Asesmen Berbasis Kelas. Materi PLPG. Undiksha. (2007).

9. Muhammadiyah 3 Depok. Skripsi tidak diterbitkan. FMIPA-UNY.

10. Musmini, Lucy Sri. Pengaruh Asesmen Portofolio dan Gaya Kognitif Terhadap Kemampuan Berpikir Produktif Mahasiswa. Jurnal Pendidikan dan Pengajaran, Jilid 45, Nomor 2. (2012).

11. Nanang Hanafiah \& Cucu Suhana. Konsep strategi pembelajaran. Bandung: PT. Refika Aditama. (2009).

12. Rizqidiaz. Kreativitas dalam Wirausaha. Diakses hari Selasa, tanggal 25 Juli 2017 dari: http://rizqidiaz.blogspot.com/2011/12/kreativitas-dalam-wirausaha. html. (2011).

13. Santyasa, I W. Model-model pembelajaran inovatif. Pelatihan Sertifikasi Guru di provinsi Bali. Undiksha. (2007).

14. Slameto. Belajar dan Faktor - Faktor yang Mempengaruhinya. Jakarta: Rineka Cipta. (2003).

15. Suarni, K. Perkembangan dan Belajar Anak. Singaraja: STKIP. (1996).

16. Sudewi. Pendekatan Penilaian Berbasis Produk pada Praktikum Cipta Boga Sebagai Upaya Meningkatkan Kualitas Pembelajaran. Jurnal Universitas Pendidikan Indonesia. Vol 5. 13. (2008).

17. Surapranata, S., \& Hatta, M. Penilaian Portofolio. Bandung: PT Remaja Rosdakarya. (2004).

18. Sutikno, M. Sobry. Menuju Pendidikan yang Bermutu. Mataram : NTP. (2004). 
19. Utami Munandar. Mengembangkan Bakat dan Kreativitas Anak Sekolah. Jakarta: Grasindo. (1992).

20. Utami. Pengembangan Kreativitas Anak Berbakat. Jakarta: Rineka Cipta. (2009).

21. Wahyudi. Asesmen Pembelajaran Berbasis Portofolio di Sekolah. Jurnal Visi Ilmu Pendidikan, Vol. 2. 1. (2010).

22. Wedasuwari, IA Made \& Sukanadi, Ni Luh. Implementasi Asesmen Portofolio Untuk Meningkatkan Kemampuan Menulis Siswa. E-Journal Santiaji Pendidikan. Volume 3. 1. (2013). 